INSTITUTION AND SURGEONS

\section{Franz Kaspar Hasselbach (1759-1816)}

\author{
Akhilesh Kumar Agarwal · Ramanuj Mukherjee
}

Received: 20 February 2007 / Accepted: 16 January 2008

\section{Biography of Dr. Franz Kaspar Hasselbach}

Dr. Hasselbach was a German physician, surgeon, and anatomist. He was born on January 27, 1759, at Hammelburg Fürstenthum Fulda. He studied medicine from 1778 in Würzburg [1]. It was his sincerity and that restless deligence attracted the attention and affection of his teachers. After noticing his enthusiasm the great Karl Kaspar von Siebold (1736-1807), who himself held the anatomy, surgery, and obstetrics chairs, made him his private pupil. He then became surgical assistant at the Julius Hospital.

He was immensely dedicated to anatomy dedicating most of his free time in dissection. On noticing his inclination for anatomy, Siebold who had had to do without the assistance of a prosector while also having to do all sectioning, made the young Hesselbach his prosector, a position he filled for six years. He was so inclined towards the subject that he worked without any financial compensation inspite of his humble background. Though he was dedicated to anatomy, Hesselbach did not neglect surgery. Due to his extraordinary aptitude for anatomy and surgery he was named assistant surgeon to Julius hospital and in 1795 published on an improved knife for stone surgery.

Even after contributing so much for the cause of medicine it was after the takeover of Würzburg by Bavaria in 1804 that he got his credit. His not too bright career was boosted and he was conferred the degree of Doctor by Würzburg medical faculty in gratitude of his contributions to the anatomical institute in 1807.

Later he was named chief surgeon at Julius hospital while also being given the permanent title of Prosector at the Anatomical Theater in Wurzburg. Among his pupils was Konrad Johann Martin Langenbeck (1776-1851), who later became a famous surgeon in Göttingen. 


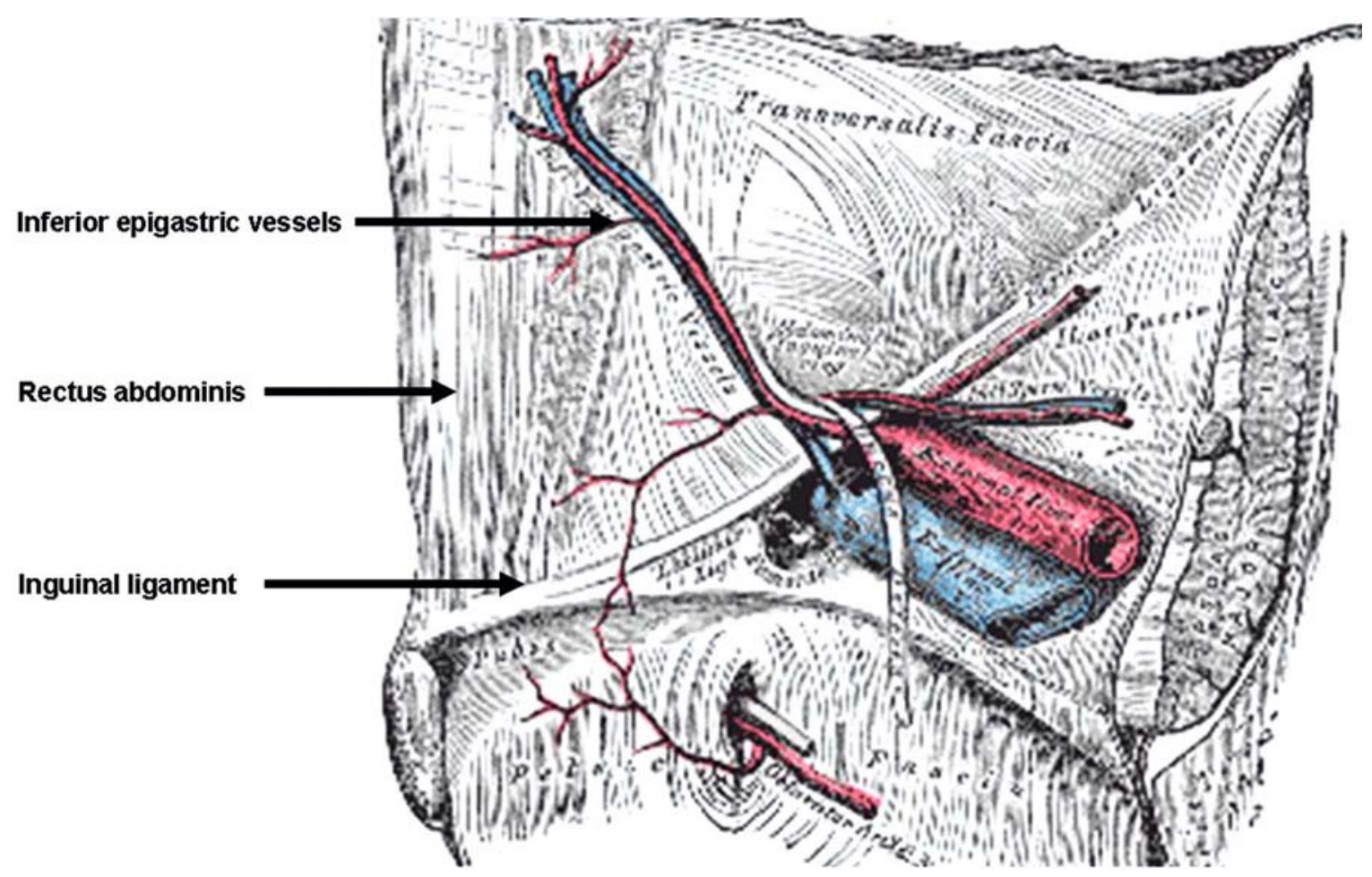

Fig. 1 Hesselbach's first impression of the triangular ingunal surface

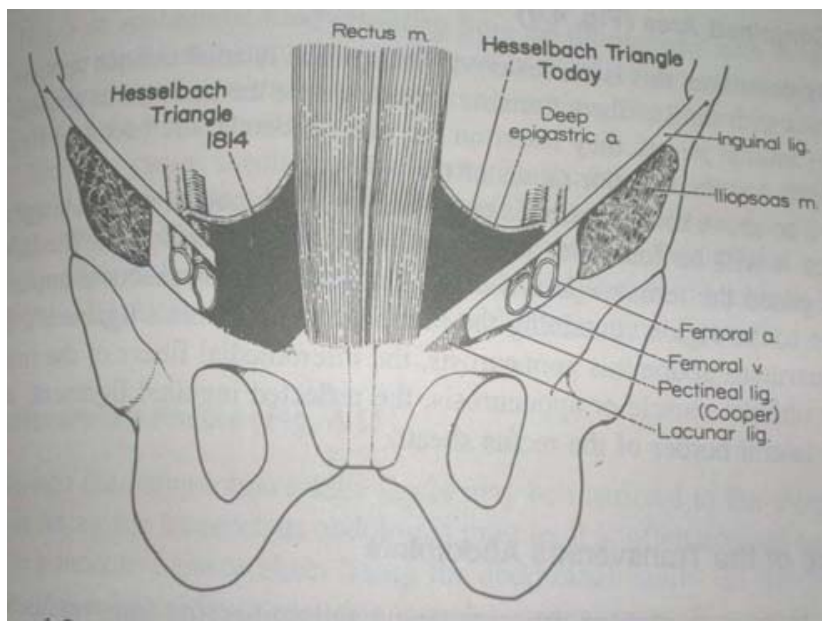

Fig. 2 Hesselbach's triangle as envisaged today

\section{Academic contributions}

There are many books illustrations written and made by him that have far ranging effect relative to furthering basic understanding of anatomy of inguinal region.

Among his written work is a massive three volume anatomic and surgical treatise Vollstandige Anleitung Zur Zergliederungskunde des Menschlicher Korpers(1805-1808).

Hesselbach's first influential contribution to hernia surgery is his 1806, Anatomic Surgery - Treatise on Origin of Inguinal Ruptures consisting of just four chapters an 32 pages in total, where he described the anatomy of groin hernia and briefly discussed the region that later came to be known as "Hesselbach's Triangle".

His work was republished eight years later as "Latest Anatomic and Pathologic Investigations concerning the origin and progress of Inguinal and Femoral hernia.' In his later monograph he first described dreyekigte Leistenflache or the 'Triangular ingunal surface' and displayed it on a copper plate. This revised edition was hailed by Marcy as 'creditable to talents and research of author' (Fig. 1).

In 1815 Hesselbach authored "Beschreibung und Abbildung eines Neuen Instrumentes zur Sichern Entdeckung und Stillung einer be idem Bruchnitte Entsandenen Gefahrkichen Bluntung' that contained description of instruments for arresting bleeding when arteries were injured during repair of Strangulated Hernia. These two works were combined and translated from vernacular to Latin as 'Disquisitiones Anatomico Pathologicae de Ortu et Progressu Herniarum Inguinalium et Cruralium'. It was this translation that had an impact in surgery throughout Europe as in those times all the physicians and surgeon read Latin, thus allowing them to quote his findings. It was now that Hesselbach's triangle became to be known as planum inguinum triangulare.

Hesselbach and Thomson reported on Ileotibial Tract as condensation of fascia transversalis internal to inguinal ligament. It was this tract that was used by Nyhus for his 
method of inferior fixation almost 200 years later in 1960 [5].

Hesselbach described the femoral hernia in 1798 and distinguished direct and indirect inguinal hernias in 1810 $[2,3]$.

\section{Associated eponyms}

Hasselbach's Fascia The cribriform fascia covering the femoral canal.

Hasselbach's Hernia A hernia of a loop of intestine that passes through the cribriform fascia presenting a lobular outline.

Hasselbachs ligament It is not a true ligament but a fibrous or muscular strands in the transversalis fascia on the medial side of the deep inguinal ring, extending from the lower border of the transversus muscle to the lacunar ligament. Also know as interfoveolar ligament (thickened transversalis fascia anterior to the epigastric vessels)

Hasselbach's Triangle It is this triangle of Hasselbach that is the basis of modern classification of Inguinal hernias. He dissected this triangle and described the boundaries of the same which from the landmarks of dissection during laparoscopic repair of hernia, unheard of during his era. The classification of direct and indirect hernia is based on, position of sac in reference to the triangle.

The triangle described by him has been modified to suit the modern management of hernia.

The triangle described by him has as its boundary (Fig. 2).
1. Superolateral : inferior epigastric vessels

2. Medial : rectus seath

3. Base : pubic pectin and pectinate ligament.

The present day triangle is described as:

1. Base : the inguinal ligament (known also as the Fallopian ligament and Poupart's ligament),

2. Medial : the exterior border of rectus muscle

3. Superolateral : the inferior epigastric vessels [4].

Surgery lost this great pioneer with the sad demise on July 24, 1816.

\section{References}

1. Vollständige Anleitung zur Zergliederungskunde des menschlichen Körpers. 3 Hefte, Rudolfstadt, 1805-1808

2. Neueste anatomisch-pathologische Untersuchungen über den Ursprung und das Fortschreiten der Keisten- und Schenkelbrüche. Würzburg, Staheliano, 1814. [Latest anatomic-pathologic investigations concerning the origin and progress of Inguinal and femoral ruptures]

3. Beschreibung und Abbildung eines neuen Instrumentes zur sicheren Entdeckung und Stillung einer bei dem Bruchsnitte entstandenen gefährlichen Blutung. Würzburg, Baumgartner, 1815. [Anatomic-surgical treatise on the origin of inguinal ruptures]

4. FK Hesselbach (1806) Anatomisch-chirurgische Abhandlung über den Urspurng der Leistenbrüche. Würzburg, Baumgärtner

5. Nyhus LM, cordon RE (1960) Clinical experience with preperitoneal hernia repair for all types of hernia of groin. Am J Surg 234:100 